\title{
Pengaruh Kualitas Layanan Akademik dan Sidang Skripsi Secara Daring Terhadap Kepuasan Mahasiswa di Masa Pandemi Covid-19
}

\author{
"Supriyadi ${ }^{1)}$, Ayu Nurul Amalia ${ }^{2)}$
}

Program Studi Pendidikan Ekonomi, Fakultas Ilmu Pendidikan, Universitas Panca Sakti Bekasi

Corresepondence author: supriyadiesbe@gmail.com

DOI: https://doi.org/10.37012/jipmht.v5i1.528

\begin{abstract}
ABSTRAK
Pandemi Corona Virus Disease (COVID-19) menerpa dunia awal tahun 2020 berdampak signifikan disegala aspek kehidupan, termasuk dunia pendidikan tinggi. Tujuan penelitian ini mengungkap kualitas layanan akademik $\left(\mathrm{X}_{1}\right)$ dan sidang skripsi daring $\left(\mathrm{X}_{2}\right)$ terhadap kepuasan mahasiswa $(\mathrm{Y})$. Penelitian ini merupakan penelitian kuantitatif dengan pendekatan survei. Sampel penelitian menggunakan teknik proportional random sampling. Sampel penelitian merujuk tabel sampel Isaac dan Michael untuk jumlah populasi 799 mahasiswa semester akhir, taraf siginifikansi $1 \%$ jumlah sampelnya adalah 363 mahasiswa. Pengambilan data menggunakan instrumen kualitas layanan akademik, sidang skripsi online dan kepuasan mahasiswa, seluruh instrumen valid dan reliabel. Analisis data menggunakan regresi ganda. Hasil penelitian mengungkapkan: 1) Persamaan regresi linear ganda $\bar{Y}=0.160+0.055 \mathrm{X}_{1}+0.216 \mathrm{X}_{2}$; 2) Kualitas layanan akademik berpengaruh positif terhadap kepuasan mahasiswa; 3) Kepuasan layanan akademik berpengaruh positif terhadap kepuasan mahasiswa 4) Terdapat pengaruh secara bersama-sama (simultan) kualitas layanan akademik dan sidang skripsi daring terhadap loyalitas mahasiswa, 5) Koefisien determinasi Pengaruh Kualitas layanan akademik dan sidang skripsi online secara bersama-sama terhadap kepuasan mahasiswa sebesar $64.4 \%$.
\end{abstract}

Kata Kunci: Kualitas Layanan Akademik, Sidang Skripsi Online, Kepuasan Mahasiswa.

\begin{abstract}
The Corona Virus Disease (COVID-19) pandemic that hit the world in early 2020 had a significant impact on all aspects of life, including the world of higher education. The purpose of this study is to reveal the quality of academic services $\left(X_{1}\right)$ and online thesis trials $\left(X_{2}\right)$ on student satisfaction $(Y)$. This research is quantitative research with a survey approach. The research sample used a proportional random sampling technique. The research sample refers to Isaac and Michael's sample table for a total population of 799 final semester students, the significance level of $1 \%$ is 363 students. Data retrieval using instruments of academic service quality, online thesis trial, and student satisfaction, all instruments are valid and reliable. Data analysis used multiple regression. The results revealed: 1) Multiple linear regression equation $=0.160+0.055 X_{1}+0.216 X_{2}$; 2) The quality of academic services has a positive effect on student satisfaction; 3) Academic service satisfaction has a positive effect on student satisfaction 4) There is a simultaneous (simultaneous) influence on the quality of academic services and online thesis trials on student loyalty, 5) Coefficient of determination Effect of Quality of academic services and online thesis trials on satisfaction students by $64.4 \%$.
\end{abstract}

Keywords: Academic Service Quality, Online Thesis Session, Student Satisfaction. 


\section{PENDAHULUAN}

Pandemi Corona Virus Disease (COVID-19) yang menerpa dunia sejak awal tahun 2020 telah berdampak signifikan pada segala aspek kehidupan, termasuk dunia pendidikan tinggi. Mudahnya penularan virus corona dan dampak kematian tinggi bagi penderitanya telah mengubah pembelajaran tatap muka yang semula mendominasi, dihentikan sementara dan didesak untuk bermigrasi ke pembelajaran berbasiskan jaringan internet. Direktorat Jenderal Pendidikan Tinggi (Ditjen Dikti), Kementerian Pendidikan dan Kebudayaan (Kemendikbud) merespon kondisi ini dengan memberikan kemudahan pembelajaran di masa darurat COVID19 kepada mahasiswa di perguruan tinggi. Tertuang dalam Surat Edaran dari Menteri Pendidikan dan Kebudayaan Nomor 36962/MPK.A/HK/2020 tanggal 17 Maret 2020 tentang Pembelajaran secara Daring dan Bekerja dari Rumah dalam rangka Pencegahan Penyebaran COVID-19.

Perguruan Tinggi harus mampu mengelola system mutu layanan maupun administrasinya. Ruang lingkup yang seperti ini akan menghasilkan sebuah system layanan yang transparan, tepat waktu, tepat jumlah dan tepat mutu. Apabila aspek-aspek seperti itu dilaksanankan dengan baik maka akan menimbulkan image keterpercayaan (reliability) dan keterjaminan (assurqnce) yang mencakup: keterpercayaan terhadap penyelenggaraan, ketepatan waktu pendidikan, dan keterjaminan berhasilnya pendidikan (Lupiyoadi 2008: 163). Dari ketiga aspek tersebut akan merefleksikan sejauh mana mutu layanan dan manajemen dari Perguruan Tinggi tersebut. Dapat dilihat bahwa perguruan tinggi sebagai salah satu pengelola jasa juga harus memperhitungkan tingkat kepuasan konsumennya agar mampu menjalankan kegiatan perkuliahan dengan baik. Hasil survei tingkat kepuasan mahasiswa yang dilakukan oleh lembaga penjaminan mutu internal (LPMI) Universitas Panca Sakti Bekasi terhadap layanan keseluruhan Universitas didapat rata-rata sebesar 53\% mahasiswa puas terhadap layanan, angka ini sudah melebihi separuh dari mahasiswa merasakan puas akan tetapi juga bukan merupakan angka yang tinggi dalam hal tingkat kepuasan, sehingga perlu dilakukan kajian yang mendalam terkait dengan layanan yang ada di Universitas Panca Sakti Bekasi. Ada beberapa layanan yang memiliki andil besar dalam mengahasilkan nilai rata-rata kepuasan mahasiswa terhadap layanan di Universitas Panca Sakti Bekasi, diantaranya adalah layanan akademik, layanan non akademik, kemahasiswaan dan kerjasama, selain 4 bidang tersebut masih ada unit pelaksana teknis Teknologi informasi, perpustakaan, laboratorium dan Lembaga Penelitian dan Pengabdian kepada masyarakat.

Berkaitan dengan adanya pandemi COVID-19 di Indonesia telah membuat sistem pembelajaran berubah secara drastis dari pembelajaran tatap muka menjadi pembelajaran di 
rumah secara online. Tidak hanya pembelajaran yang dilakukan secara online akan tetapi pelaksanaan sidang skripsi bagi mahasiswa semester akhir juga dilakukan secara online atau dalam jaringan (daring). Skripsi adalah istilah yang digunakan di Indonesia untuk mengilustrasikan suatu karya tulis ilmiah berupa paparan tulisan hasil penelitian mahasiswa program pendidikan sarjana (S1) yang membahas suatu permasalahan/fenomena dalam bidang ilmu tertentu dengan menggunakan metodologi penelitian serta kaidah-kaidah yang berlaku.

Seluruh Program Studi dan Fakultas yang ada di lingkungan Universitas Panca Sakti Bekasi semester genap tahun akademik 2019-2020 menggelar sidang tugas akhir atau Skripsi mahasiswa, pelaksanaan sidang skripsi pada saat ini berbeda dengan semester dan tahun akademik sebelumnya, pada semester ini pelaksanaan sidang skripsi melalui virtual atau Dalam Jaringan (Daring). Tugas akhir mahasiswa tersebut dipresentasikan didepan para penguji tidak ubahnya seperti pelaksanaan tatap muka langsung dengan durasi lebih kurang 40 menit setiap mahasiswa. Setiap mahasiswa diberikan waktu sekitar 10 menit melakukan presentasi didepan dua orang penguji. Ia menjelaskan mulai metode penelitian, latar belakang, konsep hingga hasil akhir penelitian. Para penguji bergantian melakukan pertanyaan atau klarifikasi atas penelitian yang dilakukan. Jika dinyatakan lolos, maka mahasiswa tersebut dipastikan lulus dari perkuliahan. Namun jika gagal, maka mahasiswa akan mengulang kembali.

Kepuasan merupakan tingkat perasaan di mana seseorang menyatakan hasil perbandingan atas kinerja produk (jasa) yang diterima dan yang diharapkan, menurut Kotler dalam Lupiyoadi (2008: 192). Kualitas berkaitan erat dengan kepuasan pelanggan. Kualitas memberikan dorongan khusus bagi para pelanggan untuk menjalin ikatan relasi saling menguntungkan dalam jangka panjang dengan perusahaan ( Tjiptono \& Chandra 2012: 115).

Kualitas berkaitan erat dengan kepuasan pelanggan. Kualitas memberikan dorongan khusus bagi para pelanggan untuk menjalin ikatan relasi saling menguntungkan dalam jangka panjang dengan perusahaan ( Tjiptono \& Chandra 2012: 115).

Hubungan antara kualitas layanan dengan kepuasan pelanggan memiliki keterkaitan dimana kepuasan pelanggan dapat menimbulkan kualitas jasa. Salah satu kemungkinan hubungan yang banyak disepakati adalah bahwa kepuasan membantu pelanggan dalam merevisi persepsinya terhadap kualitas jasa, Cronin dan Taylor (dalam Tjiptono, 2014: 295-296). Berdasarkan hasil penelitian sebelumnya yang dilakukan oleh Tjiptono (2014), menyatakan bahwa Kualitas Layanan yang terdiri dari reliability, responsivenss, assurance, emphaty,dan tangible berpengaruh positif dan signifikan terhadap kepuasan mahasiswa”. 
Tjiptono, (2007: 59). kualitas pelayanan dapat diartikan sebagai upaya pemenuhan kebutuhan dan keinginan konsumen serta ketepatan penyampaiannya dalam mengimbangi harapan konsumen. Dalam pemenuhan jasa, sebagai pemberi jasa juga harus memperhatikan setiap keinginan dari konsumen tersebut, hal ini dikarenakan konsumen menjadi faktor yang penting dalam penilaian kriteria jasa tersbut baik dari segi kualitas layanan yang ditawarkan, jasa, maupun kemampuan perusahaan dalam memenuhi jasa tersebut.

Menurut Kotler (2002: 42) "Kepuasan konsumen adalah perasaan senang atau kecewa seseorang yang berasal dari perbandingan antara kesannya terhadap kinerja (atau hasil) suatu produk dan harapan-harapannya". Yamit (2005: 78) "Kepuasan konsumen merupakan evaluasi purna beli atau hasil evaluasi setelah membandingkan apa yang dirasakan dengan harapannya". Dalam konsep kepuasan konsumen, terdapat dua elemen yang mempengaruhi yaitu harapan dan kinerja. Kotler dan Keller (2007:177) yang dikutip dari buku Manajemen Pemasaran mengatakan bahwa Kepuasan Konsumen adalah perasaan senang atau kecewa seseorang yang muncul setelah membandingkan kinerja (hasil) produk yang dipikirkan terhadap kinerja yang diharapkan.

Pelayanan menurut Zein (2009:226) adalah sebuah kata yang bagi penyedia jasa merupakan sesuatu yang harus dikerjakan dengan baik. Menurut Kotler (2002:83) definisi pelayanan adalah setiap tindakan atau kegiatan yang dapat ditawarkan oleh suatu pihak kepada pihak lain, yang pada dasarnya tidak berwujud dan tidak mengakibatkan kepemilikan apapun. Kualitas pelayanan menjadi suatu keharusan yang harus dilakukan perusahaan agar dapat mampu bertahan dan tetap mendapat kepercayaan pelanggan. Pola konsumsi dan gaya hidup pelanggan menuntut perusahaan mampu memberikan pelayanan yang berkualitas. Menurut Berry dan Zenthaml yang dalam Lupiyoadi (2006: 181) berpendapat bahwa "Keberhasilan perusahaan dalam memberikan pelayanan yang berkualitas dapat ditentukan dengan pendekatan service quality yang telah dikembangkan".

Hartono K.B., dan Salim L., (2020) judul artikel "Pengalaman Pemasaran Dan Kualitas Layanan Terhadap Loyalitas Pelanggan Dengan Kepuasan Pelanggan Dan Kepercayaan Sebagai Variabel Mediasi”. Terbit pada Jurnal Ekonomi dan Bisnis. Volume 23 . Nomor 02. Hasil penelitian menunjukkan bahwa pengalaman pemasaran dan servqual berdampak positif terhadap loyalitas pelanggan yang diperkuat oleh kepuasan dan kepercayaan pelanggan. Kepuasan pelanggan sebagai memediasi pengaruh pengalaman pemasaran dan servqual terhadap loyalitas pelanggan. Kepercayaan saja tidak dapat memediasi pengaruh pemasaran berdasarkan pengalaman pemasaran atau kualitas layanan/servqual dengan loyalitas pelanggan. Kepercayaan bersama dengan kepuasan pelanggan memediasi pemasaran 
pengalaman pemasaran dan kualitas layanan/servqual terhadap loyalitas pelanggan. Kepercayaan bisa menjadi variabel mediasi jika konsumen sudah merasakan kepuasan. Indra, N., dan Siagian, A.O. (2021) judul "Analisis Kualitas Pelayanan Kepuasan dan Pemanfaatan Teknologi Terhadap Pelanggan Go-Jek Pada Masa Pandemi Covid-19”. Terbitan Jurnal AKRAB JUARA Volume 6 Nomor 1. Hasil penelitian pengaruh yang signifikan pada ikatan pelayanan serta pemanfaatan teknologi data terhadap kepuasan pelanggan. Pada penelitian ini, tidak hanya mutu layanan yang didapat pula berpengaruh positif terhadap pemanfaatan teknologi data kepuasan serta loyalitas pelanggan. Dari penelitian penelitian yang terdahulu dan relevan, pada penelitian ini bertujuan mengungkap "Pengaruh Kualitas Layanan Akademik dan Sidang Skripsi Secara Daring Terhadap Kepuasan Mahasiswa Di Masa Pandemi Covid-19". Rumusan masalah dalam penelitian ini 1) Apakah terdapat pengaruh kualitas layanan akademik terhadap kepuasaan mahasiswa?; 2) Apakah terdapat pengaruh sidang skripsi online terhadap kepuasan layanan mahasiswa?; 3) Apakah terdapat pengaruh kualitas layanan akademik dan sidang skripsi online secara simultan terhadap kepuasan mahasiswa?. Kepuasan layanan yang dimaksud dalam penelitian ini adalah kualitas layanan yang dimaksud dalam penelitian ini adalah kualitas layanan akademik mahasiswa dan sidang skripsi secara daring (online). Untuk kepuasaan layanan mahasiswa yaitu kepuasaan mahasiswa pada kualitas layanan akademik dan sidang skripsi secara daring (virtual) di Universitas Panca Sakti Bekasi. Seluruh variabel ini diteliti pada masa pandemi Covid-19.

\section{METODE}

Penelitian ini merupakan penelitian kuantitatif asosiatif dengan menggunakan metode survei, seluruh mahasiswa semester akhir Universitas Panca Sakti Bekasi yang sedang melaksanakan tugas akhir atau skripsi sebagai populasi dalam penelitian ini, sebanyak 799 mahasiswa dari 3 Fakultas yaitu Fakultas Ilmu Pendidikan dengan program studi: Pendidikan Guru Pendidikan Anak Usia Dini (PGPAUD), Pendidikan Ekonomi dan Pendidikan Bahasa Inggris; Fakultas Ekonomi dan Bisnis terdiri dari Program Studi: Manajemen dan Akuntansi; Fakultas Sains dan Teknologi terdiri dari dua program pendidikan diploma dan sarjana untuk Diploma Program Studi Manajemen Informatika, Komputerisasi Akuntansi, untuk program pendidikan sarjana meliputi Teknik Informatika dan Sistem Informatika. Jumlah sampel penelitian ini mengacu pada tabel sampel Isaac dan Michael dengan tingkat taraf kesalahan (significance level) $1 \%$ didapat jumlah sampel sebanyak 363 mahasiswa dari total keseluruhan 799 mahasiswa. Teknik sampel yang digunakan yaitu teknik Proportional Random Sampling yaitu pengambilan sampel dilakukan secara proporsional per fakultas dan per program studi 
semester akhir yang melaksanakan sidang skripsi di semester genap tahun akademik 20192020. Pengumpulan data berupa skor diambil dengan menggunakan instrumen kualitas layanan akademik, instrumen persepsi mahasiswa pelaksanaan sidang skripsi virtual dan kepuasan layanan. Seluruh instrumen penelitian valid dan reliabel. Hipotesa penelitian: 1) Diduga terdapat pengaruh kualitas layanan akademik terhadap kepuasaan mahasiswa; 2) Diduga terdapat pengaruh sidang skripsi online terhadap kepuasan layanan mahasiswa; 3) diduga terdapat pengaruh kualitas layanan akademik dan sidang skripsi online secara simultan terhadap kepuasan mahasiswa. Uji hipotesis dengan analisis regresi ganda.

\section{HASIL DAN PEMBAHASAN}

\section{Hasil}

Setelah didapat data penelitian selanjutnya data penelitian dideskripsikan sebagai berikut: 1). Variabel Kualitas layanan Akademik jumlah responden sebanyak 363 mahasiswa dengan skor terendah 2 dan skor tertinggi 10, dengan rata-rata skor (mean) sebesar 8.149, rentang skor 8, simpangan baku atau standard deviasi 1.938, skor yang sering muncul (modus) 10, nilai tengah (median) 9; 2). Variabel Sidang Skripsi Secara Daring jumlah responden sebanyak 363 mahasiswa dengan skor terendah 9 dan skor tertinggi 20, dengan rata-rata skor (mean) sebesar 17.124, rentang skor 11, simpangan baku atau standard deviasi 2.519, skor yang sering muncul (modus) 20, nilai tengah (median) 17; 3). Variabel Kepuasan Layanan Mahasiswa jumlah responden sebanyak 363 mahasiswa dengan skor terendah 2 dan skor tertinggi 5, dengan rata-rata skor (mean) sebesar 4.314, rentang skor 3, simpangan baku atau standard deviasi 0.725 , skor yang sering muncul (modus) 5, nilai tengah (median) 4. Berikut dibawah ini tabel deskripsi data variabel penelitian.

Tabel 1.

Deskripsi Data Variabel Penelitian

\begin{tabular}{lccccccccc}
\hline & N & Mean & Median & Mode & Variance & Range & Min & Max & $\begin{array}{c}\text { Std. } \\
\text { Deviation }\end{array}$ \\
\hline $\begin{array}{l}\text { Kualitas Layanan } \\
\text { Akademik (X1) }\end{array}$ & 363 & 8.1488 & 9 & 10 & 3.757 & 8 & 2 & 10 & 1.93825 \\
$\begin{array}{l}\text { Sidang Skripsi Online atau } \\
\begin{array}{l}\text { Daring (X2) } \\
\text { Kepuasaan Mahasiswa (Y) }\end{array}\end{array}$ & 363 & 17.124 & 17 & 20 & 6.346 & 11 & 9 & 20 & 2.51922 \\
& 463 & 4.314 & 4 & 5 & 0.525 & 3 & 2 & 5 & 0.72485 \\
\hline
\end{tabular}




\section{Hasil uji hipotesis sebagai berikut:}

Persamaan Linear Ganda dan Uji Signifikansi Koefisien Persamaan Regresi. Dari tabel coefficients di atas, diperoleh konstanta $b_{0}=0.160$ koefisien regrasi $b_{1}=0.055$, dan $b_{2}=$ 0.216. Sehingga persamaan regresi linear ganda adalah $\bar{Y}=0.160+0.055 \mathrm{X}_{1}+0.216 \mathrm{X}_{2}$. Hipotesis: $\mathrm{H}_{0}: \beta_{1}<0$ vs $\mathrm{H}_{1}: \beta_{1}>0$ dan $\mathrm{H}_{0}: \beta 2<0$ vs $\mathrm{H}_{1}: \beta_{2}>0$. Dari hasil analisis seperti disarikan pada tabel menujukan harga statistik untuk koefisien variable $\mathrm{X}_{1}$ yaitu $\mathrm{t}_{\text {hitung }}=4.521$ dan p-velue $=0 / 2=0.000<0.05$ (uji pihak kanan), atau $\mathrm{H}_{0}$ ditolak yang bermakna Kualitas layanan akademik berpengaruh positif terhadap Kepuasan mahasiswa. Selanjutnya harga statistik untuk koefisien variable $\mathrm{X}_{2}$ yaitu $\mathrm{t}_{\text {hitung }}=23.115$ dan $\mathrm{p}$-velue $=0 / 2=0<0.05$ (uji pihak kanan), atau $\mathrm{H}_{0}$ ditolak, yang bermakna Sidang skripsi secara online atau daring berpengaruh positif terhadap Kepuasan mahasiswa;

Tabel 2.

Tabel Coefficients

\begin{tabular}{|c|c|c|c|c|c|c|}
\hline & \multirow{2}{*}{ Model } & \multicolumn{2}{|c|}{$\begin{array}{c}\text { Unstandardized } \\
\text { Coefficients } \\
\end{array}$} & \multirow{2}{*}{$\begin{array}{c}\begin{array}{c}\text { Standardized } \\
\text { Coefficients }\end{array} \\
\text { Beta } \\
\end{array}$} & \multirow{2}{*}{$\mathbf{t}$} & \multirow{2}{*}{ Sig. } \\
\hline & & B & $\begin{array}{l}\text { Std. } \\
\text { Error }\end{array}$ & & & \\
\hline \multirow{3}{*}{1} & (Constant) & 0.16 & 0.167 & & 0.958 & 0.339 \\
\hline & $\begin{array}{l}\text { Kualitas Layanan } \\
\text { Akademik }\end{array}$ & 0.055 & 0.012 & 0.147 & 4.521 & 0 \\
\hline & $\begin{array}{l}\text { Sidang Skripsi Online } \\
\text { atau Daring }\end{array}$ & 0.216 & 0.009 & 0.752 & 23.115 & 0 \\
\hline
\end{tabular}

Uji Signifikansi Persamaan Regresi Ganda. $\mathrm{H}_{0}:=\beta_{1}=\beta_{2}$ atau $\mathrm{H}_{0}: \beta_{1}-\beta_{2}=0$ dan $\mathrm{H}_{1}:=\beta_{1}=$ $\beta_{2}$ atau $H_{1}: \beta_{1}-\beta_{2}=0$. Dari hasil analisis yang disarikan pada tabel ANOVA di atas diperoleh, harga statistik $\mathrm{F}_{\text {hitung }}=324.918$, dan p-velue $=0.000<0.05$ atau hal ini berarti $\mathrm{H}_{0}$ ditolak. Artinya terdapat pengaruh linear variabel kualitas layanan akademik dan sidang skripsi online atau daring dengan kepuasan mahasiswa. Hal ini juga bermakna terdapat pengaruh secara bersama-sama (simultan) kualitas layanan akademik dan sidang skripsi online atau daring terhadap kepuasan mahasiswa;

Tabel 3.

ANOVA $^{\mathrm{a}}$

\begin{tabular}{llccccc}
\hline \multirow{2}{*}{ Model } & $\begin{array}{c}\text { Sum of } \\
\text { Squares }\end{array}$ & df & $\begin{array}{c}\text { Mean } \\
\text { Square }\end{array}$ & F & Sig. \\
\hline \multirow{4}{*}{1} & Regression & 122.394 & 2 & 61.197 & 324.918 & $.000^{\mathrm{b}}$ \\
\cline { 2 - 7 } & Residual & 67.804 & 360 & 0.188 & & \\
\cline { 2 - 7 } & Total & $\mathbf{1 9 0 . 1 9 8}$ & $\mathbf{3 6 2}$ & & & \\
\hline
\end{tabular}


Uji Signifikansi Koefisien Korelasi Ganda. Hipotesis statistik: H0 $: \rho<0$ dan $\mathrm{H}_{1}: \rho>0$ Uji signifikansi koefisien korelasi ganda diperoleh dari tabel model summary di atas. Terlihat bahwa koefisien korelasi ganda $\left(\mathrm{R}_{\mathrm{y} .12}\right)=0.802$ dan Fhit $($ Fchange $)=324.918$, serta $\mathrm{p}$-velue $=$ $0.000<0.05$ atau $\mathrm{H}_{0}$ ditolak. Dengan demikian koefisien korelasi ganda antara $\mathrm{X}_{1}$ dan $\mathrm{X}_{2}$ dengan Y adalah berarti atau signifikan. Sedangkan koefisien determinasi ditunjukan oleh $\mathrm{R}$ Square $=0,644$, yang mengandung makna bahwa $64.4 \%$ variabilitas variabel Kepuasan mahasiswa (Y) dapat di jelaskan oleh Kualitas layanan akademik $\left(\mathrm{X}_{1}\right)$ dan Sidang Skripsi Online atau Daring $\left(\mathrm{X}_{2}\right)$, sehingga dapat di simpulkan bahwa pengaruh Kualitas layanan akademik dan Sidang skripsi online atau daring secara bersama-sama terhadap Kepuasan mahasiswa sebesar $64.4 \%$;

Tabel 4.

Model Summary

\begin{tabular}{|c|c|c|c|c|c|c|c|c|c|}
\hline \multirow[b]{2}{*}{ Model } & \multirow[b]{2}{*}{$\mathbf{R}$} & \multirow[b]{2}{*}{$\begin{array}{c}\mathbf{R} \\
\text { Square }\end{array}$} & \multirow{2}{*}{$\begin{array}{c}\text { Adjusted } \\
\text { R } \\
\text { Square }\end{array}$} & \multirow{2}{*}{$\begin{array}{l}\text { Std. Error } \\
\text { of the } \\
\text { Estimate }\end{array}$} & \multicolumn{5}{|c|}{ Change Statistics } \\
\hline & & & & & $\begin{array}{c}\mathbf{R} \\
\text { Square } \\
\text { Change } \\
\end{array}$ & $\begin{array}{c}\text { F } \\
\text { Change }\end{array}$ & df1 & df2 & $\begin{array}{c}\text { Sig. F } \\
\text { Change }\end{array}$ \\
\hline 1 & $.802^{\mathrm{a}}$ & 0.644 & 0.642 & 0.43399 & 0.644 & 324.918 & 2 & $360^{\mathrm{a}}$ & 0 \\
\hline
\end{tabular}

Uji Signifikansi Koefisien Korelasi Parsial.

Korelasi Antara Kualitas layanan akademik $\left(\mathrm{X}_{1}\right)$ dan Kepuasan mahasiswa (Y) dengan mengontrol pengaruh sidang skripsi online atau daring $\left(\mathrm{X}_{2}\right)\left(\mathrm{r}_{\gamma 1.2}\right)$. Dari hasil analisis pada tabel di atas diperoleh $\left(\mathrm{r}_{\gamma 1.2}\right)=0,232$ dan p-velue $=0.000<0,05$ atau $\mathrm{H}_{0}$ ditolak. Dengan demikian, koefisien korelasi antara Kualitas layanan akademik $\left(\mathrm{X}_{1)}\right.$ dan kepuasan mahasiswa (Y) dengan mengontrol variabel Sidang Skripsi Online atau Daring $\left(\mathrm{X}_{2}\right)$ adalah signifikan;

Tabel 5.

Correlations

\begin{tabular}{|c|c|c|c|c|}
\hline \multicolumn{3}{|c|}{ Control Variables } & $\begin{array}{c}\text { Kualitas Layanan } \\
\text { Akademik }\end{array}$ & $\begin{array}{l}\text { Kepuasaan } \\
\text { Mahasiswa }\end{array}$ \\
\hline \multirow{6}{*}{$\begin{array}{l}\text { Sidang } \\
\text { Skripsi } \\
\text { Online atau } \\
\text { Daring }\end{array}$} & \multirow{3}{*}{$\begin{array}{l}\text { Kualitas } \\
\text { Layanan } \\
\text { Akademik }\end{array}$} & Correlation & 1 & 0.232 \\
\hline & & $\begin{array}{l}\text { Significance (1- } \\
\text { tailed) }\end{array}$ & . & 0 \\
\hline & & $\begin{array}{l}\text { tailed) } \\
\text { df }\end{array}$ & 0 & 360 \\
\hline & \multirow{3}{*}{$\begin{array}{l}\text { Kepuasaan } \\
\text { Mahasiswa }\end{array}$} & Correlation & 0.232 & 1 \\
\hline & & $\begin{array}{l}\text { Significance (1- } \\
\text { tailed) }\end{array}$ & 0 & . \\
\hline & & df & 360 & 0 \\
\hline
\end{tabular}

Korelasi Antara sidang skripsi online atau daring $\left(\mathrm{X}_{2}\right)$ dan Kepuasan mahasiswa $(\mathrm{Y})$ dengan mengontrol pengaruh Kualitas layanan akademik $\left(\mathrm{X}_{1}\right)$. Hasil analisis diperoleh $\left(\mathrm{r}_{\gamma 2.1}\right)=0,773$, 
dan p-velue $=0,000<0.05$ atau H0 ditolak. Dengan demikian, koefisien korelasi antara Kepuasan layanan $\left(\mathrm{X}_{2}\right)$ dan Loyalitas mahasiswa $\mathrm{Y}$ dengan mengontrol variabel Kualitas layanan $\left(\mathrm{X}_{1}\right)$ adalah signifikan.

Tabel 6.

Correlations

\begin{tabular}{|c|c|c|c|c|}
\hline \multicolumn{3}{|c|}{ Control Variables } & $\begin{array}{l}\text { Kepuasaan } \\
\text { Mahasiswa }\end{array}$ & $\begin{array}{c}\text { Sidang Skripsi } \\
\text { Online atau Daring } \\
\end{array}$ \\
\hline \multirow{6}{*}{$\begin{array}{l}\text { Kualitas } \\
\text { Layanan } \\
\text { Akademik }\end{array}$} & \multirow{3}{*}{$\begin{array}{l}\text { Kepuasaan } \\
\text { Mahasiswa }\end{array}$} & Correlation & 1 & 0.773 \\
\hline & & $\begin{array}{l}\text { Significance (1- } \\
\text { tailed) }\end{array}$ & . & 0 \\
\hline & & $\mathrm{df}$ & 0 & 360 \\
\hline & \multirow{3}{*}{$\begin{array}{l}\text { Sidang Skripsi } \\
\text { Online atau } \\
\text { Daring }\end{array}$} & Correlation & 0.773 & 1 \\
\hline & & $\begin{array}{l}\text { Significance (1- } \\
\text { tailed) }\end{array}$ & 0 & . \\
\hline & & $\mathrm{df}$ & 360 & 0 \\
\hline
\end{tabular}

\section{Pembahasan}

\section{Kualitas Layanan Akademik Berpengaruh Positif Terhadap Kepuasan Mahasiswa}

Hasil Penelitian ini sejalan dengan teori Kotler (2002: 42) "Kepuasan konsumen adalah perasaan senang atau kecewa seseorang yang berasal dari perbandingan antara kesannya terhadap kinerja (atau hasil) suatu produk dan harapan-harapannya". Menurut Tjiptono \& Chandra (2012: 115) Kualitas berkaitan erat dengan kepuasan pelanggan. Kualitas memberikan dorongan khusus bagi para pelanggan untuk menjalin ikatan relasi saling menguntungkan dalam jangka panjang dengan perusahaan. Masih menurut Tjiptono, (2007: 59). kualitas pelayanan dapat diartikan sebagai upaya pemenuhan kebutuhan dan keinginan konsumen serta ketepatan penyampaiannya dalam mengimbangi harapan konsumen. Kepercayaan bersama dengan kepuasan pelanggan memediasi pemasaran pengalaman pemasaran dan kualitas layanan/servqual terhadap loyalitas pelanggan. Kepercayaan bisa menjadi variabel mediasi jika konsumen sudah merasakan kepuasan. Indra, N., dan Siagian, A.O. (2021) judul "Analisis Kualitas Pelayanan Kepuasan Dan Pemanfaatan Teknologi Terhadap Pelanggan Go-Jek Pada Masa Pandemi Covid-19”. Terbitan Jurnal AKRAB JUARA Volume 6 Nomor 1. Hasil penelitian pengaruh yang signifikan pada ikatan pelayanan serta pemanfaatan teknologi data terhadap kepuasan pelanggan. Pada penelitian ini, tidak hanya mutu layanan yang didapat pula berpengaruh positif terhadap pemanfaatan teknologi data kepuasan serta loyalitas pelanggan. Dengan demikian hipotesa pertama penelitian ini didukung oleh data empiris. 


\section{Sidang Skripsi Online atau Daring Berpengaruh Positif Terhadap Kepuasan Mahasiswa}

Hasil penelitian ini mendukung teori Berry dan Zenthaml yang dalam Lupiyoadi (2006: 181) berpendapat bahwa "Keberhasilan perusahaan dalam memberikan pelayanan yang berkualitas dapat ditentukan dengan pendekatan service quality yang telah dikembangkan". Hasil penelitian ini sejalan dengan penelitian Asrul N.A. (2020) artikel dengan judul "Ekspektasi Dan Tingkat Kepuasan Mahasiswa Terhadap Kualitas Layanan Pendidikan Secara Daring Selama Pandemi Covid 19”, terbit pada Vol 16 No 2 (2020): Jurnal Administrasi Publik Puslatbang KMP LAN, hasil penelitian terdapat 6 faktor yang menjadi prioritas utama dalam proses perbaikan layanan pendidikan. Setidaknya ada 7 faktor yang patut dipertahankan dalam menjaga kualitas layanan pendidikan. Dua faktor yang dianggap kurang penting dan kurang memuaskan. Serta 5 faktor yang dianggap kurang penting tapi kinerja memuaskan. Perlu adanya strategi untuk memperbaiki layanan pendidikan secara daring selama pandemi covid-19 dalam upaya peningkatan kepuasan mahasiswa sesuai yang dibutuhkan. Dengan demikian hipotesis kedua penelitian ini dikukung oleh data empiris.

\section{Terdapat Pengaruh Secara Bersama-sama (Simultan) Kualitas Layanan Akademik dan Sidang Skripsi Online atau Daring Terhadap Kepuasan Mahasiswa}

Hasil penelitian ini sejalan dengan penelitian Indra, N., dan Siagian, A.O. (2021) judul “Analisis Kualitas Pelayanan Kepuasan Dan Pemanfaatan Teknologi Terhadap Pelanggan GoJek Pada Masa Pandemi Covid-19". Hasil penelitian pengaruh yang signifikan pada ikatan pelayanan serta pemanfaatan teknologi data terhadap kepuasan pelanggan. Pada penelitian ini, tidak hanya mutu layanan yang didapat pula berpengaruh positif terhadap pemanfaatan teknologi data kepuasan serta loyalitas pelanggan. menurut Kotler (2002: 42) "Kepuasan konsumen adalah perasaan senang atau kecewa seseorang yang berasal dari perbandingan antara kesannya terhadap kinerja (atau hasil) suatu produk dan harapan-harapannya". Menurut Tjiptono \& Chandra (2012: 115) Kualitas berkaitan erat dengan kepuasan pelanggan. Kualitas memberikan dorongan khusus bagi para pelanggan untuk menjalin ikatan relasi saling menguntungkan dalam jangka panjang dengan perusahaan. Kepuasan pelanggan sebagai memediasi pengaruh pengalaman pemasaran dan servqual terhadap loyalitas pelanggan. Kepercayaan saja tidak dapat memediasi pengaruh pemasaran berdasarkan pengalaman pemasaran atau kualitas layanan/servqual dengan loyalitas pelanggan. Kepercayaan bersama dengan kepuasan pelanggan memediasi pemasaran pengalaman pemasaran dan kualitas layanan/servqual terhadap loyalitas pelanggan. Hasil penelitian ini mendukung teori Berry dan Zenthaml yang dalam Lupiyoadi (2006: 181) berpendapat bahwa "Keberhasilan perusahaan dalam memberikan pelayanan yang berkualitas dapat ditentukan dengan 
pendekatan service quality yang telah dikembangkan". Hasil penelitian ini sejalan dengan penelitian Asrul N.A. (2020) artikel dengan judul "Ekspektasi Dan Tingkat Kepuasan Mahasiswa Terhadap Kualitas Layanan Pendidikan Secara Daring Selama Pandemi Covid 19”, terbit pada Vol 16 No 2 (2020): Jurnal Administrasi Publik Puslatbang KMP LAN, hasil penelitian terdapat 6 faktor yang menjadi prioritas utama dalam proses perbaikan layanan pendidikan. Setidaknya ada 7 faktor yang patut dipertahankan dalam menjaga kualitas layanan pendidikan. Dua faktor yang dianggap kurang penting dan kurang memuaskan. Serta 5 faktor yang dianggap kurang penting tapi kinerja memuaskan. Perlu adanya strategi untuk memperbaiki layanan pendidikan secara daring selama pandemi covid-19 dalam upaya peningkatan kepuasan mahasiswa sesuai yang dibutuhkan. Dengan demikian hipotesis ketiga dalam penelitian ini didukung oleh data empiris.

\section{SIMPULAN DAN REKOMENDASI}

Dari hasil penelitian dan pembahasan dapat disimpulkan: 1) Kualitas layanan akademik berpengaruh positif terhadap kepuasan mahasiswa; 2) Sidang skripsi online atau daring berpengaruh positif terhadap kepuasan mahasiswa 3) Terdapat pengaruh secara bersama-sama (simultan) kualitas layanan akademik dan Sidang sripsi online/daring terhadap kepuasaan mahasiswa; 4) Koefisien determinasi Pengaruh Kualitas layanan akademik dan Sidang Skripsi online atau daring secara bersama-sama terhadap kepuasan mahasiswa sebesar $64.4 \%$

\section{REFERENSI}

1. Arikunto, S. 2009. Manajemen Penelitian. Jakarta: PT Rieka Cipta.

2. Asrul N.A. (2020) artikel dengan judul "Ekspektasi Dan Tingkat Kepuasan Mahasiswa Terhadap Kualitas Layanan Pendidikan Secara Daring Selama Pandemi Covid 19”, terbit pada Vol 16 No 2. Link Vol 16 No 2 (2020): Jurnal Administrasi Publik Puslatbang KMP LAN

3. Hartono K.B., dan Salim L., (2020) judul artikel "Pengalaman Pemasaran Dan Kualitas Layanan Terhadap Loyalitas Pelanggan Dengan Kepuasan Pelanggan Dan Kepercayaan Sebagai Variabel Mediasi”. Terbit pada Jurnal Ekonomi dan Bisnis. $\begin{array}{llllll}\text { Volume } & 23 & \text {. } & \text { Nomor } & 02 . & \text { Link }\end{array}$ https://jurnal.unikal.ac.id/index.php/jebi/article/view/1215

4. Huriyati, Ratih. 2010. Bauran Pemasaran dan Loyalitas Konsumen. Alfabetha: Bandung. 
5. Kerlinger, F. N. 2006. Asas-Asas Penelitian Behavioral. Yogyakarta: Gadjah Mada University Press.

6. Kotler, Philip, dan Amstrong. 2009. Dasar-dasar pemasaran. Edisi Kesembilan. PT. Indeks: Jakarta.

7. Kotler, Philip. 2005. Manajemen Pemasaran. Jilid 1 dan 2. PT. Indeks. Kelompok Gramedia: Jakarta.

8. Kotler, Philip. 2008. Manajemen Pemasaran di Indonesia (Analisis, Perencanaan, Implementasi dan Pengendalian). Salemba Empat: Jakarta.

9. Lupiyoadi, Rambat. 2013. Manajemen Pemasaran Jasa. Edisi Ketiga. Salemba Empat: Jakarta.

10. Supriyadi. 2018. Pengaruh Pendekatan Pembelajaran, Kecerdasan Emosional dan Kecerdasan Adversitas terhadap Hasil Belajar Videografi, Disertasi. Jakarta: Universitas Negeri Jakarta

11. Siagian, A.O. 2021 Analisis Kualitas Pelayanan Kepuasan Dan Pemanfaatan Teknologi Terhadap Pelanggan Go-Jek Pada Masa Pandemi Covid-19. Jurnal Akrab. Link. http://akrabjuara.com/index.php/akrabjuara/article/view/1384

12. Sugiono. 2008. Metode Penelitian Pendekatan Kuantitatif, Kualitatif dan R \& D. Alfa Beta: Bandung.

13. Tjiptono, Fandy. 2007. Manajemen Jasa. Andi: Yogyakarta.

14. Umar, Husein. 2003. Metode Riset Komunikasi Organisasi. PT. Gramedia Pustaka Utama: Jakarta.

15. Yusi, M. Syahirman dan Umiyati, Idris. 2009. Metodologi Penelitian Ilmu Sosial: Pendidikan Kuantitatif. Indonesia. Penerbit: Citra Books Indonesia.

16. Yamit, Zulian. 2006. Manajemen Kualitas Produk dan Jasa. Yogyakarta: Ekonisia. 